\title{
Collision between a migrating lesser spotted eagle (Clanga pomarina) and an aircraft as detailed by fine-scale GSM-GPS telemetry data
}

\author{
Kolízia medzi migrujúcim orlom krikl’avým (Clanga pomarina) a lietadlom opísaná \\ pomocou presných GSM-GPS telemetrických údajov
}

\author{
Bernd-Ulrich MEYBURG, Tadeusz MIZERA, Christiane MEYBURG \& Michael McGRADY
}

\begin{abstract}
We tracked a breeding adult female lesser spotted eagle (Clanga pomarina) from Germany using GPS technology, and provide details of her collision with a small aircraft at Rzeszów (SE Poland) during April 2016, when she was migrating towards her breeding territory. The ultimate fate of the bird was not established until the tag was found by chance and the data were recovered. Bird strikes are a global problem with sometimes lethal consequences for animals and people. This account highlights the way technology allows us to closely monitor events during bird migration, and document human-raptor interactions. The collision illustrates how food availability might affect bird-strike risk, and indicates that removing animal carcasses from the vicinity of airports could reduce that risk. We discuss the data in relation to risks faced by lesser spotted eagles (and other soaring birds) of collision with aircraft, especially along flyways during migration seasons.
\end{abstract}

\begin{abstract}
Abstrakt: Hniezdiacu dospelú samicu orla krikl'avého (Clanga pomarina) sme sledovali pomocou technológie GPS. V tomto príspevku prinášame informácie o jej kolízii s malým lietadlom v Rzeszówe (JV Pol’sko) počas jej migrácie na hniezdisko v apríli 2016. Príčina úhynu orlice nebola známa až do nájdenia vysielačky a získania dát. Kolízie vtákov s lietadlami sú celosvetovým problémom, niekedy s letálnymi následkami pre zvieratá aj l'udí. Zdôrazňujeme tu spôsob, akým nám technológia umožňuje detailne sledovat' udalosti počas migrácie orlice a dokumentovat' interakcie medzi človekom a dravcom. Kolízia ilustruje to, ako môže dostupnost' potravy ovplyvnit’ riziko zrážky a poukazuje na to, že odstraňovanie kadáverov uhynutých zvierat z blízkosti letísk ho môže zmiernit'. Získané údaje diskutujeme vo vzt’ahu k riziku, ktoré hrozí orlom krikl'avým (a iným vtáčím druhom využívajúcim plachtenie) pri kolízii s lietadlom, najmä pozdĺž t’ahových trás počas obdobia migrácie.
\end{abstract}

Key words: bird strike, mortality, flight hazard, satellite tracking, soaring migrants, Poland, aircraft

Bernd-Ulrich Meyburg, BirdLife Germany (NABU), P. O. Box 330451, 14199 Berlin, Germany.

E-mail: BUMeyburg@aol.com

Tadeusz Mizera, Poznań University of Live Sciences, Zoology Dep. Wojska Polskiego 71 c, 60-625 Poznań, Poland

Christiane Meyburg, World Working Group on Birds of Prey, 31, Avenue du Maine, 75015 Paris, France

Michael McGrady, International Avian Research, Am Rosenhügel 59, 3500 Krems, Austria

Acknowledgements: Dr. P. Howey (Microwave Telemetry, Inc. (USA)) provided the then experimental GSM tag, free access to software for handling the large amount of data, and much helpful information. J. Matthes and Ulf Kraatz helped B. Meyburg trapping the eagle, and fitting it with the GSM tag. Trapping and tagging were done under permit from the Vogelschutzwarte Brandenburg (Brandenburg State Bird Conservation Centre). The authors would like to thank the pilot of the aircraft, S. Bańkowski, and airport personnel, J. Płonka and J. Kaczmarek, for providing useful information about the event. R. Micał found the remains of the eagle. He also returned the transmitter, which allowed the recovery of data stored in the tag's memory. The almost complete skeleton is now conserved at Poznán University. N. Sapir provided information on bird strike from the Israeli Air Force bird collision database.

\section{Introduction}

Bird collisions with aircraft (bird strikes) are a global problem that can result in catastrophic loss of human life (http://www.spiegel.de/wissenschaft/mensch/voegel-legen-jet-turbinen-lahm-toedliche-gefahr-am-himmel-a-601606.html), expensive aircraft repairs and loss of operational time for commercial and military aircraft (Allan \& Orosz 2001, Thorpe 2003, Kitowski 2011). Moreover, bird strikes almost always result in the death of the bird. Most bird strikes occur near airports, at relatively low altitudes (Dolbeer 2006, https://www.faa.gov/airports/airport_safety/wildlife/faq/), 
and curtailing of preferred habitats and food accessibility for birds at and near airports is carried out to discourage birds from using those areas, thereby reducing bird strike risk (e.g. Blackwell \& Wright 2006, Merriman et al. 2007, Blackwell et al. 2013). However, soaring species, including eagles and vultures of conservation concern (see Shamoun-Baranes et al. 2003), might also be at risk at higher altitudes, especially when migrating.

As part of a larger study, we tracked an adult breeding female lesser spotted eagle via satellite. After more than $2 \frac{1}{2}$ years of tracking, the eagle collided with an aircraft and died. Because telemetry data were collected at short intervals, and the remains of the bird and the tag were recovered, we were able to document in detail the eagle's movements prior to the collision. Information from the airport and from the pilot provided additional detail. We know of no other accounts of bird collisions which include such detailed information about the bird's behaviour just prior to the incident.

Raptors and other birds also collide with other things, including cars, drones, buildings and powerlines (Erickson et al. 2005), and wind energy turbines pose an increasing threat (see: de Lucas et al. 2007), including along the flyway used by lesser spotted eagles (e.g. Leshem 1992, Leshem et al. 1999, BirdLife International 2017a). Understanding more about flight, migration and foraging can help reduce the risk of mortality from these anthropomorphic sources, and help conservation. We discuss the data in terms of potential risk to eagles and humans, and the opportunity which tracking technology offers for better understanding of bird-strike risk.

\section{Materials and methods}

On July 25, 2013 we fitted a breeding adult female lesser spotted eagle, "Marta", with a $25 \mathrm{~g}$ solar-powered GSM-GPS tag (Microwave Telemetry, Inc., USA) as a backpack (Meyburg \& Fuller 2007). The tag was fitted in her breeding territory, and she weighed $1520 \mathrm{~g}$. The tag recorded latitude, longitude, speed, bearing and altitude at a maximum rate of once per minute. Constraints related to solar power and views of GPS satellites meant that for the time period about which we report, locations were recorded every 11.2 minutes on average, but more frequently during the day. When there were no clouds (e.g. during 08:17-13:47 local time (Central European Summer Time $=\mathrm{UTC}+2 \mathrm{hr}$ ) on April 19), the average interval between locations was 2 $\min 22 \mathrm{sec} ; 43.9 \%$ of the locations were separated by one minute. Unless otherwise stated, time is reported in UTC. Our observations were made when the eagle was on spring migration from her wintering grounds in south-eastern Africa (esp. Mozambique, Swaziland, South Africa). Information gathered from airport records and telephone interviews with the pilot provided further detail about the incident we report here.

\section{Results}

The bird crossed the Bosporus on April 14, 2016 between 09:15-09:26 UTC (around noon local time), and proceeded for the next 5.5 days towards the breeding territory she had occupied for at least three years. At about 15:08 on April 19 she stopped and roosted for the night of April 19-20 about $11 \mathrm{~km}$ southwest of the city of Rzeszów $\left(49.942^{\circ} \mathrm{N}, 21.955^{\circ} \mathrm{E}\right)$ (Fig. 1). At about 06:33 on April 20 the eagle left her roost and continued migration, heading NW. At 07:38, the transmission of data suddenly stopped; the last location was at $49.973^{\circ}$ $\mathrm{N}, 21.866^{\circ} \mathrm{E}$.

Observations at the breeding site confirmed that the GPS-tracked female never arrived, and at that time her fate was unknown. Her mate, who was also equipped with a GSM-GPS tag, stayed alone in the territory until the end of May, when he paired with a new, unmarked female. The pair did not breed successfully.

On August 21, 2016, the remains (complete skeleton and feathers) of the tracked eagle were found, along with the transmitter, the ringing station ring and the colour-ring, in a forest by a mushroom picker, who informed the senior researcher by email. The remains were found at $50.112^{\circ} \mathrm{N}, 21.993^{\circ} \mathrm{E}$, about $18.5 \mathrm{~km}$ north-east of the last uploaded location. The transmitter was returned to us and we were able to download the data which had been collected and stored, but not transmitted.

The recovered data revealed that the bird had flown northward for about $18 \mathrm{~km}$, skirting the city of Rzeszów, Poland, and deviating from the most direct course towards her breeding territory (Fig. 2), located over 750 $\mathrm{km}$ to the NW (approx. 307 ${ }^{\circ}$. Between 08:54-09:09 she stopped near a major road (E40); recovered altitude data suggest that the eagle was either on the ground or perched in a low tree. From that place she moved east about $1.25 \mathrm{~km}$ to a place near the same road, and stayed there between 09:25 and 09:42, again probably on the ground. She then moved a short distance further east, gained about $140 \mathrm{~m}$ in altitude and at 10:11 crossed the west end of the Rzeszów airport runway, where she ap- 
Fig. 1. Migration path used by the adult female lesser spotted eagle in the days preceding collision with an aircraft on April 20, 2016. Yellow dots=GPS locations received via GSM transmissions, red dots = GPS locations retrieved from recovered transmitter.

Obr. 1. Migračná trasa dospelej samice orla kriklavého $v$ dňoch pred kolíziou s lietadlom, ku ktorej došlo 20. apríla 2016. Žlté body = GPS súradnice prijaté pomocou GSM, červené body = GPS súradnice prijaté $z$ nájdenej vysielačky.

Fig. 2. Movements of the adult female lesser spotted eagle between 08:54-10:23 hrs April 21, 2016.

Obr. 2. Pohyb dospelej samice orla krikl'avého 21. apríla 2016 v čase od 08:54 do 10:23 hod.
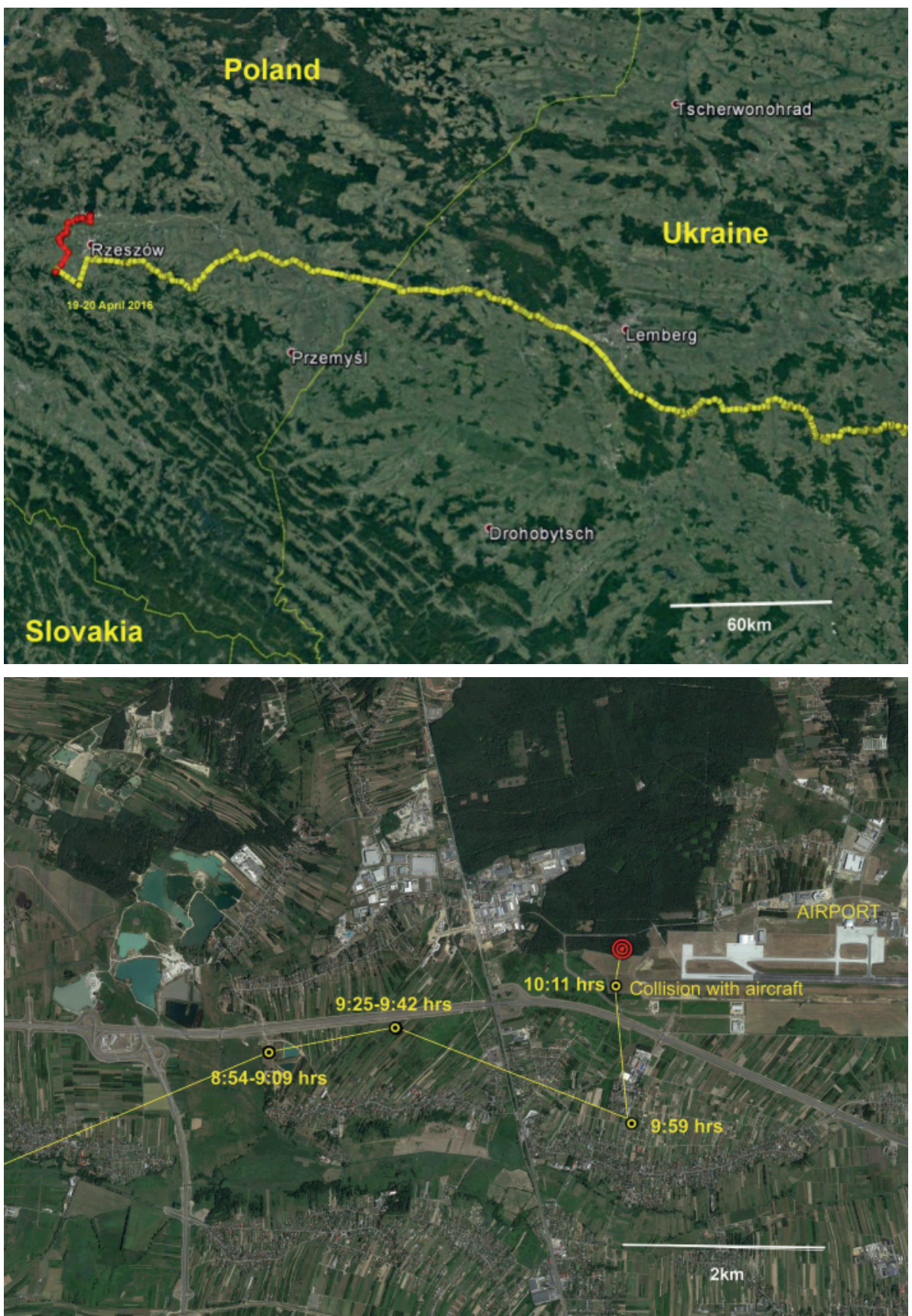

parently collided with an aircraft. At the time of the collision the transmitter data show that the eagle was travelling at $7.4 \mathrm{~km} / \mathrm{hr} \mathrm{NNW}\left(41^{\circ}\right)$, at an altitude of about $128 \mathrm{~m}$. The recovered data covered 23 locations collected prior to the collision, and many locations where the bird was found, about $170 \mathrm{~m}$ north of where the colli- sion occurred, and $70 \mathrm{~m}$ from the forest edge. After the eagle left her night-time roost on April 20 until the time of collision, GPS locations were being collected on average every $6.9 \pm 4.9 \mathrm{~min}$.

By consulting airport records, it was determined that at precisely 10:11 a non-commercial, single-engine 
Cessna aircraft had taken off from the airport, heading west. We contacted the pilot, who reported that he was unaware of any collision. The weather on April 20 at the airport was seasonal $\left(\mathrm{Temp} \max =12{ }^{\circ} \mathrm{C}\right.$, Temp $\min =$ $5{ }^{\circ} \mathrm{C}$, some clouds ( 7 hrs of sunlight) and a variable, but mostly westerly wind with a mean speed of $18 \mathrm{~km} / \mathrm{hr}$ ).

\section{Discussion}

We detail the collision of a migrating adult female lesser spotted eagle with a small aircraft taking off from the Rzeszów airport, a small international airport in SW Poland that serves non-commercial aircraft and commercial flights mainly from Warsaw, London and $\mathrm{Mu}-$ nich.

Bird strike is a global problem, and the International Civil Aviation Organization (ICAO) recommends that airports take steps to monitor and reduce the hazard (Sodhi 2002). Our account is probably the first confirmed incident involving a lesser spotted eagle, but is consistent with the findings of Dolbeer (2006) that bird strikes occur most commonly near airports, and often go unreported (Linnel et al. 1999) even, as in this case, when the bird is large. However, Dolbeer's (2006) finding that most collisions occur at lower altitudes is based on analyses of all bird species, and may not hold for the risk faced by soaring birds, including eagles, especially when they are on migration.

Although we know of no confirmed collisions with lesser spotted eagles, there are incidents suspected as being with lesser spotted eagles or reported as such. On September 29, 1961 a 'dark-coloured' eagle collided with a military jet (Gloster Meteor) in Israel, and penetrated the canopy (Schekler et al. 2018). The captain and single crew member reported that they saw a "big dark raptor" (N. Sapir, pers. comm.). Although the species was not unequivocally identified at the time by DNA testing, late September is when the peak of the lesser spotted eagle migration occurs in Israel. Another reported possible collision with a lesser spotted eagle happened in Israel in winter (Schekler et al. 2018), but in our view this most probably involved a greater spotted eagle (Clanga clanga) which, unlike the lesser spotted eagle, regularly winters in Israel.

The collision we report was accidental, but some cases of eagle-aircraft interactions are driven by apparent aggressive behaviour of eagles directed toward aircraft intruding on eagle territories. Jenny (2010) compiled data on collisions of golden eagles (Aquila chrysaetos) with powered aircraft, gliders and paragliders in the Alps. Of the 20 cases of documented collisions, at least two-thirds were aggressive attacks by eagles. Mikiara (1990) reported the case of a lesser spotted eagle attacking a glider. Such interactions, particularly with recreational "flying" by humans, have led to research and the development of strategies for reducing such incidents (Brendel et al. 2002).

Collisions between birds and aircraft are not necessarily simple random events. The risk of collision can be affected by factors such as food availability and weather, and these factors need to be considered when trying to understand why individual collisions occur. In the case of this eagle, tracking data suggest that she may have been attracted to road-killed animals, and deviated from her migration path to a location closer to the airport, and this would have increased the risk of collision. In order to feed, the eagle lost altitude, which would also have increased the collision risk, and as a result of feeding, the eagle would have been carrying the extra weight of her meal and would perhaps have been less manoeuvrable. After feeding the eagle may have been intending to fly into the forest to roost and digest her meal.

Weather (e.g. Martin \& Shaw 2010) and vision (Martin et al. 2012) can also influence the probability of collision by affecting bird flight behaviour or visibility (bird or pilot) (Gauthreaux 1991, Manville 2005). However, the weather conditions at Rzeszów airport on May 20, 2016 did not include high winds or poor visibility, and it does not appear that they contributed to any increased risk of collision.

The vast majority of lesser spotted eagles which migrate successfully in autumn cross the Bosporus (Turkey), fly south in a fairly narrow stream to Suez (Egypt) and continue, still in a rather narrow stream, to the southern end of Lake Tanganyika (Tanzania), from where most disperse toward various destinations from Angola in the west to Mozambique further south-east (Meyburg \& Meyburg 2009). None of the 50-plus adults tracked so far have wintered north of the southern end of Lake Tanganyika (Meyburg unpublished). Spring migration follows essentially the same path in reverse (Meyburg et al. 1995, 2004), except in East Africa where they mostly arrive at the Red Sea coast in Eritrea, then migrate rather close to the coast, resulting in the autumn route which is more inland (Meyburg et al. 2007, Meyburg \& Meyburg 2009). During these migrations, the eagles pass through bottlenecks where there is a heightened risk of collision with aircraft. Bird-strike 
risk and incidents in Israel, which is along the flyway used by lesser spotted eagles and other soaring birds (Leshem et al. 1999, Richardson \& West 2000), have spawned research which seeks to understand bird migration through the bottleneck there, so that adjustments to flights by commercial and military aircraft can be made to avoid collisions (Leshem 1992, Leshem \& Shamoun-Baranes 2000, Shamoun-Baranes et al. 2003). The Bosporus is another, similar bottleneck. The wide variety and large number of raptors, including lesser spotted eagles (e.g. Zalles \& Bildstein 2000), migrating through this area (and aircraft flying there) are at risk of collision, especially with the construction of the new international airport (Meyburg \& Meyburg 2015). Once finished, the airport will be enormous and located north of Istanbul's urban sprawl (at approx. $41.28^{\circ} \mathrm{N}, 28.79^{\circ}$ E), directly on one of the most important Eurasian flyways. Millions of migrating birds, including large soaring species such as lesser spotted eagles and white storks (Ciconia ciconia), pass through this area twice every year, and as mentioned above, the risk to soaring birds on migration, especially at an airport located at a bottleneck location like the Bosporus, may be serious even at relatively high altitudes. Surprisingly, and despite the potential risk to humans and birds, we could find no assessment of impacts in the public domain, although potential changes in land use arising from the construction and operation of the airport are discussed by Karacor \& Korshid (2015).

Aircraft are not the only collision hazard faced by birds, including raptors. Carrion is often found close to roads, and eagles and other scavenging birds feeding on road-kill are at greater risk of being hit by a passing vehicle (Forman \& Alexander 1998, Sherwood et al. 2002). If our assumptions about the events of April 20 are correct, then the eagle we were tracking was at a heightened risk of collision when she was feeding near or on the road, before she was hit by the aircraft. Certainly the number of roads and traffic volumes have increased dramatically in recent decades, and small and large animals are killed regularly. In Germany it seems that it is becoming more common for eagles to be observed along roads (see Fig. 3 and 4). As a result, eagle collision fatalities are probably also increasing. In the short time since the summer of 2017, nest-site wardens have reported two adult lesser spotted eagles being killed on roads in Germany. Moreover, a juvenile lesser spotted eagle tracked by us was hit by a car in Sudan; it suffered a broken wing, but survived (unpublished).
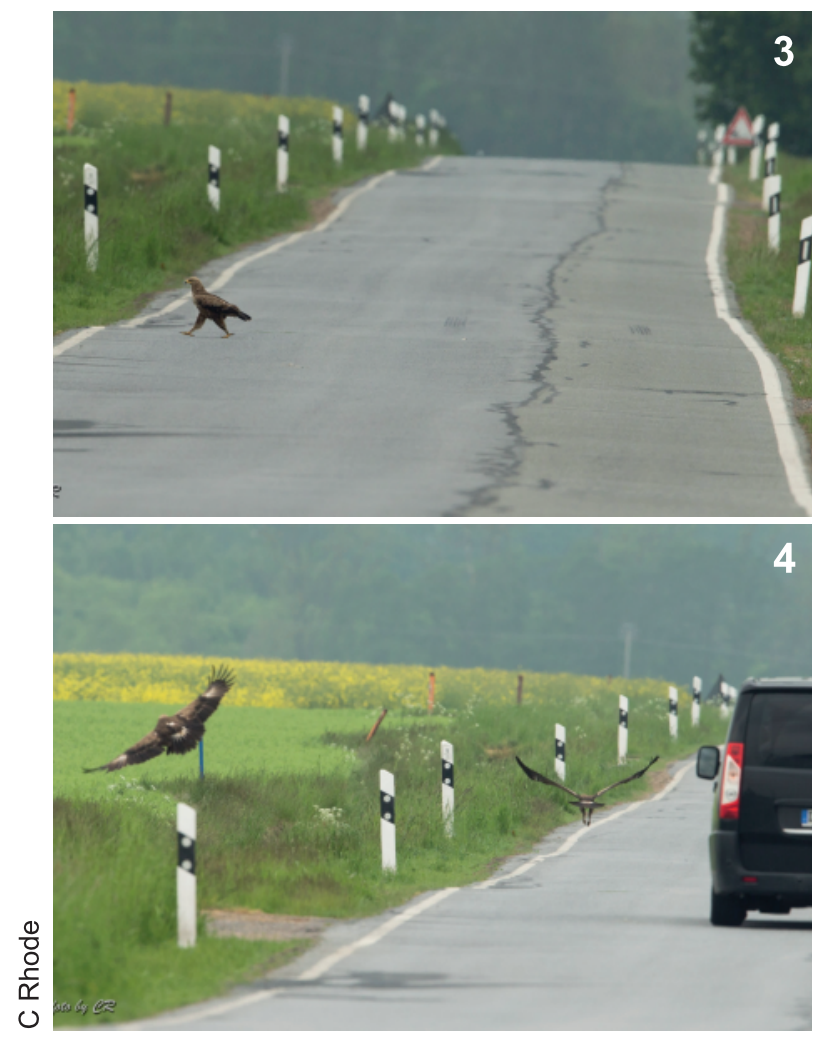

Fig. 3-4. Lesser spotted eagle on a road (3) and avoiding traffic on a road in Germany (4).

Obr. 3-4.Orol kriklavý na ceste (3) a vyhýbajúci sa autám v Nemecku (4).

Thus removal of carcasses near roads, even if they are not near airports, might reduce the mortality of lesser spotted eagles and other scavenging birds.

Although the migration flyway for lesser spotted eagles can be narrow, and is punctuated by bottlenecks, the eagles can detect food and forage over large areas, meaning actual risk of collision is probably greater than is immediately apparent from maps of migration. A lesser spotted eagle being tracked by us in September 2012 diverted some $18 \mathrm{~km}$ off its migratory trajectory, dwelling there for 1.5-3.5 days, apparently while it fed on carrion.

Globally, the lesser spotted eagle is of "Least Concern" (BirdLife International 2017b) in terms of its conservation, although declining populations across its wide range show that its status is deteriorating (Meyburg et al. 2001, 2004). It is listed in Annex I of Directive 2009/147/EC of the European Parliament and of the 
Council on the Conservation of Wild Birds (EU Birds Directive). In Germany, where our bird used to breed, the lesser spotted eagle is considered at risk of extermination (e.g. Gedeon et al. 2014, Völkler et al. 2014). Wind farms are a new, serious risk for lesser spotted eagles (e.g. Grünkorn 2015, Langgemach \& Dürr 2018). Despite being of least concern across its range, it is the only large raptor species that breeds in Germany which is imperilled, and as such is specially protected under German national law (e.g. Meyburg et al. 2004). The same is true for other countries at the western border of its range (e.g. the Czech Republic, Hungary). Lesser spotted eagles face a variety of threats across their annual range (e.g. Meyburg et al. 2001, BirdLife International 2017b). Collisions between lesser spotted eagles and aircraft have not been recorded so far, though studies in Israel suggest they have occurred (Y. Leshem pers. comm.).

The population growth rate of long-lived birds, such as lesser spotted eagles, is sensitive to changes in survival (Stahl \& Oli 2006, Krüger al. 2010), particularly of adults. The loss of an experienced breeding adult is particularly harmful to small, declining populations at the edge of their global breeding range. Even if lost birds are replaced immediately, new recruits are seldom successful in their first year as breeders (as was the case here; see Böhner \& Langgemach 2004), and lower reproductive success may continue into subsequent years. It is well known in Germany that lesser spotted eagles breeding near wind farms have lower breeding success (Scheller 2007), probably because the loss of adults to collision with turbines goes unnoticed.

Therefore, if this incident is merely an example of a fairly common, but poorly documented phenomenon, then there could be cause for concern, especially since aircraft collisions form only a portion of the deadly interactions birds can have with anthropogenic objects (e.g. cars, trucks, wind turbines, powerlines or buildings). After her death, her partner (also fitted with a transmitter in 2013) eventually obtained a new mate, though breeding was unsuccessful in 2016. In February 2017 that male disappeared at a stopover near a military airport in Zambia during the spring migration. There was no successful breeding of eagles at the site in 2017. It will be interesting to see how long it will take for a new pair at the old breeding site occupied for decades to reproduce successfully.

Bird strikes can be costly, although the incident with Marta caused no apparent damage to the aircraft, lost time or injury. The total cost of bird strike to large transport aircraft worldwide is estimated at $\$ 1-1.5$ billion annually (Allan 2000, Allan \& Orosz 2001). Reducing interactions between birds and aircraft is beneficial for human safety, and for financial and bird conservation reasons; it is also important for maintaining military preparedness. Certainly, better understanding of bird movement could help to ameliorate the problem of bird strike, whether with aircraft or other objects, and transmitters which locate birds accurately in three dimensions are an important new technology. Research and education of pilots and airport personnel are important facets of implementing effective ways of reducing collision risk (Sodhi 2002, DeVault et al. 2013, Viljoen \& Bouwman 2016).

\section{References}

Allan JR 2000: The costs of bird strikes and bird strike prevention. Human Conflicts with Wildlife: Economic Considerations. Paper 18. Retrieved March 14, 2017 from http://digitalcommons.unl.edu/nwrchumanconflicts/18.

Allan JR \& Orosz AP 2001: The cost of birdstrikes to commercial aviation. 2001 Birdstrike Committee USA/Canada. Third Joint Meeting. Calgary, Canada. Paper 2. Retrieved March 14, 2017 from http://digitalcommons.unl.edu/birdstrike2001/2.

Böhner J \& Langgemach T 2004: Warum kommt es auf jeden einzelnen Schreiadler Aquila pomarina in Brandenburg an? Ergebnisse einer Populationsmodellierung. Vogelwelt 125: 271-281.

BirdLife International 2017a: Migratory soaring bird project. Wind energy guidance - birds and wind farms within the Rift Valley/Red Sea flyway. Retrieved November 13, 2017 from http://migratorysoaringbirds.undp.birdlife.org/sites/default/files/factshe et $\% 20$ Wind $\% 20$ Farm $\% 20$ Developer\%20new $\% 20 \log \% \% 20 P R . p d f$.

BirdLife International 2017b: Species factsheet: Clanga pomarina. Retrieved March 14, 2017 from http://www.birdlife.org.

Blackwell BF, Seamans TW, Schmidt PM, Vault TL, Belant JL, Whittingham MJ, Martin JA \& Fernández-Juricic E 2013: A framework for managing airport grasslands and birds amidst conflicting priorities. Ibis 155: 199-203.

Blackwell BF \& Wright SE 2006: Collisions of redtailed hawks (Buteo jamaicensis), turkey vultures (Cathartes aura), and black vultures (Coragyps at- 
ratus) with aircraft: implications for bird strike reduction. Journal of Raptor Research 40: 76-80.

Brendel UM, Eberhardt R \& Wiesmann K 2002: Conservation of the golden eagle (Aquila chrysaetos) in the European Alps - a combination of education, cooperation, and modern techniques. Journal of Raptor Research 36: 20-24.

de Lucas M, Janss GFE \& Ferrer M (eds) 2007: Birds and windfarms - risk assessment and mitigation. Quercus, Madrid.

DeVault TL, Blackwell BF \& Belant JL (eds) 2013: Wildlife in airport environments: preventing animalaircraft collisions through science-based management. Johns Hopkins University Press, Baltimore.

Dolbeer RA 2006: Height distribution of birds recorded by collisions with civil aircraft. USDA National Wildlife Research Center - Staff Publications. Paper 500. Retrieved March 14, 2017 from http://digitalcommons.unl.edu/icwdm usdanwrc/500.

Erickson WP, Johnson GD \& David Jr P 2005: A summary and comparison of bird mortality from anthropogenic causes with an emphasis on collisions, 1029-1042. In: Ralph CJ \& Rich TD (eds), Bird Conservation Implementation and Integration in the Americas: Proceedings of the Third International Partners in Flight Conference. March 20-24, 2002; Asilomar, California. Volume 2 Gen. Tech. Rep. PSW-GTR-191. Albany, CA: US Dept. of Agriculture, Forest Service, Pacific Southwest Research Station.

Forman RTT \& Alexander LE 1998: Roads and their major ecological effects. Annual Review Ecology and Systematics 29: 207-231.

Gauthreaux SA 1991: The flight behavior of migrating birds in changing wind fields: radar and visual analyses. American Zoologist 31: 187-204.

Gedeon K, Grüneberg C, Mitschke A, Sudfeldt C, Eickhorst W, Fischer S, Flade M, Frick S, Geiersberger I, Koop B, Kramer M, Krüger T, Roth N, Ryslavy T, Stübing S, Sudmann SR, Steffens R, Vökler F \& Witt K 2014: Atlas Deutscher Brutvogelarten. SVD und DDA, Hohenstein-Ernstthal und Münster.

Grünkorn T 2015: A large-scale, multispecies assessment of avian mortality rates at onshore wind turbines in northern Germany (PROGRESS). Conference on Wind Energy and Wildlife Impacts (CWW) March 10-12, 2015. Berlin.

Jenny D 2010: Kollisionen zwischen Steinadlern Aquila chrysaetos und Flugzeugen in den Alpen. Ornitho- logische Beobachter 107: 101-110.

Karacor EK \& Korshid D 2015: Projected environmental effects of the third airport in Istanbul. Journal of Food, Agriculture \& Environment 13: 223-227.

Kitowski I 2011: Civil and military birdstrikes in Europe: an ornithological approach. Journal of Applied Sciences 11: 183-191.

Köppel J (ed.) 2017: Wind energy and wildlife interactions. Springer, Cham. DOI: 10.1007/978-3-31951272-3.

Krüger O, Grünkorn T \& Struwe-Juhl B 2010: The return of the white-tailed eagle (Haliaeetus albicilla) to northern Germany: modelling the past to predict the future. Biological Conservation 143: 710-721.

Langgemach T \& Dürr T 2018: Informationen über Einflüsse der Windenergienutzung auf Vögel. Stand 12. Februar 2018. Landesamt für Umwelt Brandenburg, Staatliche Vogelschutzwarte. Retrieved March 7, 2018 from http://www.lugv.brandenburg.de/media_fast $/ 4055 / v s w \_d o k w i n d$ voegel.pdf.

Leshem J, Leshem Y, Bahat O \& Lachman E 1999: Flying with the birds. Tel-Aviv University, Tel Aviv.

Leshem Y 1992: Predicting the regularity of bird migration in global bottleneck areas on a daily, seasonal, and yearly scale, and its implementation in the Israel Air Force and civilian flight, 243-258. In: Proceedings of the 21st Bird Strike Committee Europe, Jerusalem.

Leshem Y \& Shamoun-Baranes J 2000: Flight safety, internet and education - a leading tool for global awareness, 17-21. In: Proceedings of $25^{\text {th }}$ International Bird Strike Committee Meeting. Amsterdam, Netherlands.

Manville II AM 2005: Bird strike and electrocutions at power lines, communication towers, and wind turbines: state of the art and state of the science-next steps toward mitigation, 1051-1064. In: Ralph CJ \& Rich TD (eds), Bird Conservation Implementation and Integration in the Americas: Proceedings of the Third International Partners in Flight Conference. March 20-24, 2002; Asilomar, California. Volume 2 Gen. Tech. Rep. PSW-GTR-191. Albany, CA: US Dept. of Agriculture, Forest Service, Pacific Southwest Research Station.

Martin GR, Portugal SJ \& Murn CP 2012: Visual fields, foraging and collision vulnerability in Gyps vultures. Ibis 154: 626-631.

Martin GR \& Shaw JM 2010: Bird collisions with power lines: Failing to see the way ahead? Biolo- 
gical Conservation 143: 2695-2702.

Merriman JW, Boal CW, Bashore TL, Zwank PJ \& Wester DB 2007: Abundance of diurnal raptors in relation to prairie dog colonies: implications for bird-aircraft strike hazard. Journal of Wildlife Management 71: 811-815.

Meyburg B-U \& Fuller MR 2007: Satellite tracking, 242-248. In: Bird DM \& Bildstein KL (eds), Raptor research and management techniques. Hancock House Publishers, Surrey.

Meyburg B-U, Haraszthy L, Strazds M \& Schäffer N 2001: European Species Action Plan for lesser spotted eagle (Aquila pomarina), 1-24. In: Schäffer N \& Gallo-Orsi U (eds), European Union action plans for eight priority bird species. Office for Official Publications of the European Communities, Luxembourg, 24.

Meyburg B-U, Langgemach T, Graszynski K \& Böhner J 2004: The situation of the lesser spotted eagle Aquila pomarina in Germany: The need for an action plan and active conservation, 601-613. In: Chancellor RD \& Meyburg B-U (eds), Raptors Worldwide. WWGBP \& MME, Budapest.

Meyburg B-U \& Meyburg C 2009: Satelliten-Telemetrie beim Schreiadler (Aquila pomarina). Labus, Naturschutz im Landkreis Mecklenburg-Strelitz, Sonderheft 13: 16-44.

Meyburg B-U \& Meyburg C 2015: Mortal danger - do not fly to Istanbul during bird migration! In: Dravecký M \& Guziová Z (eds), Abstracts of contributions presented at the International Conference on the Conservation of the Lesser Spotted Eagle, Slovakia, 2014. Slovak Raptor Journal 9: 71-93. DOI: 10.151 5/srj-2015-0006.

Meyburg B-U, Meyburg C, Bělka T, Šreibr O \& Vrana J 2004: Migration, wintering and breeding of a lesser spotted eagle (Aquila pomarina) from Slovakia tracked by satellite. Journal of Ornithology 145: $1-7$.

Meyburg, B-U, Meyburg C, Matthes J \& Matthes H 2007: Heimzug, verspätete Frühjahrsankunft, vorübergehender Partnerwechsel und Bruterfolg beim Schreiadler Aquila pomarina. Vogelwelt 128: 21-31.

Meyburg B-U, Scheller W \& Meyburg C 1995: Zug und Überwinterung des Schreiadlers Aquila pomarina: Satellitentelemetrische Untersuchungen. Journal of
Ornithology 136: 401-422.

Mikiara Š 1990: Lesser spotted eagle (Aquila pomarina) attacking glider. Buteo 5: 101-102.

Richardson WJ \& West T 2000: Serious birdstrike accidents to military aircraft: updated list and summary, 67-98. In: Proceedings of 25th International Bird Strike Committee Meeting. Amsterdam, Netherlands.

Shamoun-Baranes J, Leshem Y, Yom-Tov Y \& Liechti O 2003: Differential use of thermal convection by soaring birds over central Israel. Condor 105: 208-218.

Scheller W 2007: Standortwahl von Windenergieanlagen und Auswirkungen auf die Schreiadlerbrutplätze in Mecklenburg-Vorpommern. Naturschutzarb. Meckl.-Vorp. 50: 12-22.

Schekler I, Troupin D, Leshem Y \& Sapir N 2018: Birdaircraft collision database of the Israeli air force. Excerpt from unpublished report. Animal Flight Lab, University of Haifa, Israel.

Sherwood B, Cutler D \& Burton J 2002: Wildlife and roads. The ecological impact. Imperial College Press, London.

Sodhi NS 2002: Competition in the air: birds versus aircraft. The Auk 119: 587-595.

Stahl JT \& Oli MK 2006: Relative importance of avian life-history variables to population growth rate. Ecological Modelling 198: 22-39.

Thorpe J 2003: Fatalities and destroyed civil aircraft due to bird strikes, 1912-2002. In: International Bird Strike Committee, 26th Meeting. Warsaw, Poland.

Viljoen IM \& Bouwman H 2016: Conflicting traffic: characterization of the hazards of birds flying across an airport runway. African Journal of Ecology 54: 308-316.

Vökler F, Heinze B, Sellin D \& Zimmermann H 2014: Rote Liste der Brutvögel Mecklenburg-Vorpommerns. Ministerium für Landwirtschaft, Umwelt und Verbraucherschutz Mecklenburg-Vorpommern, Schwerin.

Zalles JI \& Bildstein KL 2000: Raptor watch: a global directory of raptor migration sites. BirdLife International and Hawk Mountain Sanctuary, Cambridge, UK and Kempton, USA. 